\title{
HOMER, FROM RECEPTION TO COMPOSITION
}

\author{
BARBARA GRAZIOSI
}

Durhan University

Resumo. Esse artigo pretende contribuir com duas áreas dos estudos homéricos que
raramente parecem entrar em um diálogo produtivo: crítica textual e estudos de recep-
ção. Ele acessa três abordagens diferentes do texto de Homero: as edições da Ilíada e da
Odisseia de H. van Thiel, a da Ilíada de Martin West para a Teubner e a abordagem mul-
titextual de Gregory Nagy; ao mesmo tempo, ele leva a sério a ênfase crescente na re-
cepção nos estudos clássicos. Ao levar em conta variantes textuais, morfologia e sintaxe,
esse artigo ilustra como o estudo de recepção pode contribuir para a constituição do
texto e, vice-versa, como a história do texto homérico ilumina sua recepção mais ampla.
Palavras-chave. Homero, crítica textual, recepção, variantes textuais, morfologia, sintaxe.

THIS PAPER AIMS TO CONTRIBUte TO TWO AREAS OF HOMERIC SCHOLARSHIP which seldom seem to engage in productive dialogue: textual criticism and reception studies. ${ }^{1}$ From the point of view of the textual critic, those who study the reception of classical texts often seem to operate at a level far removed from textual detail, and even farther removed from the constitution of a correct text. From the point of view of classical reception scholars, textual critics may seem engaged in a discipline that has now largely lost its urgency, and even perhaps its raison d'être. Greek and Latin texts are generally well served by up-to-date and rigorously documented editions; so it may be tempting to conclude that the task of editing is essentially accomplished, and that scholars may now move on to other tasks, such as precisely that of studying the reception of classical literature in a variety of different cultural and historical contexts. There is some strength to this position, and there are certainly other ancient literatures (for example cuneiform literatures) which are in much more urgent need of up-to-date editions, and even of first editions. ${ }^{2}$ Still, even in classics, editing remains a concern. This is perhaps best illustrated by the recent publication of two

${ }^{1}$ A welcome exception to this general dearth of dialogue is Battezzato 2003.

2 Even the most famous Babylonian text, The Epic of Gilgamesh, received the first full edition, translation and commentary just one decade ago: George 2003. 
radically different editions of the Iliad: one by van Thiel for Olms (1996), the other by West for Teubner (1998-2000).

These two editions start from different principles and, unsurprisingly, arrive at significantly different texts. Helmut van Thiel trusts the Homeric Vulgate, that is to say the best medieval manuscripts. He takes the position that ancient variants transmitted in the Homeric scholia are usually marginal notes which once featured in the texts of ancient scholars (for example Zenodotus'), and that they are therefore of little significance when reconstructing the Homeric text. He also insists that modern editors not indulge in conjectures of their own. What they should do, rather, is represent the medieval Vulgate as faithfully as possible. He concedes that this is a modest aim, but one which he regards as appropriate to what can and cannot be known about the Homeric text. According to him, "laurels in textual criticism are not to be won from the text of Homer". ${ }^{3}$ West would surely disagree: his edition is a dazzling piece of editorial showmanship. He does not trust the medieval Vulgate, and sees his task as that of exposing and mending its shortcomings. In order to restore what he thinks was the original wording of the Homeric text, West makes use of poorly attested ancient variants; and, above all, employs his own critical acumen to weed out corruption and modernisation from the transmitted text. ${ }^{4}$

It is perhaps unsurprising that these two editions, with their very different approaches to the Homeric text, have sparked a lively debate. ${ }^{5}$ One important participant in that debate, though not an editor himself, is Gregory Nagy who has argued, in several successive publications, that the Homeric text evolved over a long period of time, from a stage of relative fluidity in the Dark Age to one of relative stability in the late Hellenistic period. He consequently advocates an inclusive approach to variant readings, which he broadly regards as equally valid realisations of a developing multitext. ${ }^{6}$ Nagy's approach has found many adherents, but also staunch critics. Richard Janko, Margalit Finkelberg and others have pointed out that the degree of textual variation found in the Homeric poems is quite modest compared to the multiformity that prevails in other oral traditions, including some ancient Greek traditions. ${ }^{7}$ Quotations of Homer in classical authors display some divergences that go beyond single words - but, it must

\footnotetext{
${ }^{3}$ See van Thiel 1991, xxiv.

${ }^{4}$ For his principles, see West 1973 and, especially, 2001.

5 E.g. Janko 2000; Nagy 2000 and 2003; Nardelli 2001; Rengakos 2002; West 2001 and 2004.

6 On Nagy's multitext, see http://www.homermultitext.org/

See Finkelberg 2000, with earlier literature.
} 
be said, not much beyond single words. ${ }^{8}$ Early Ptolemaic papyri also differ from the medieval Vulgate in some of their readings ("horizontal variation") and in the number of lines ("vertical variation"); though again even these so-called "wild papyri" are not as wild as all that. ${ }^{9}$ What we see, at least from the classical period onward, is a text of the Iliad and Odyssey that is essentially stable, significantly more so than, say, the Asian Mahabharata traditions or even the poems of the epic cycle, as Finkelberg rightly points out. More importantly, it is my view that where variant readings do exist, it is often possible to distinguish between more and less compelling ones.

When working with Johannes Haubold on an edition and commentary of Iliad 6, we found that there were fewer variants than we had expected, and that on the whole they seemed to answer to Hellenistic tastes: they seemed motivated by a desire to elucidate the text; make Homeric language more context-specific; or address perceived lapses of decorum..$^{10}$ These findings confirmed Fantuzzi's argument that Hellenistic scholars tended to adjust Homeric poetry to the sensibilities of their age.11 This does not exclude the possibility that some of the readings favoured by the Alexandrians represented genuine early variants, ${ }_{1}^{12}$ but if that is what they are, they survived because they suited Hellenistic readers. It would be dangerous to generalise from our reading of book 6 to the whole of the Iliad, since there are reasons why our sample may display less textual variation than the poem as a whole: Iliad 6 is, after all, a very tightly composed episode. Still, the sample shows that, in some cases at least, variants are evidence for the reception of Homeric epic, and not just of the possible multiformity of its composition.

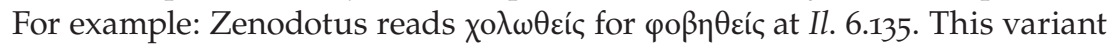
is not only poorly attested but also explicable: it seems designed to restore dignity to the god, an issue which exercised Homeric readers. The variant reading is plainly not on a par with the Vulgate text. The editor's task of sifting, explaining and ranking individual Homeric readings thus remains an important one, and a democratic "multitext" approach will certainly be misleading, if it seeks to grant equal status to all variants.

The editions by van Thiel, West, and the multitext approach championed by Nagy summarise the current state of play concerning the textual criticism of Homer. As for the study of reception, there is no doubt

\footnotetext{
${ }^{8}$ Labarbe 1949 collects and discusses Homeric quotations in Plato.

${ }^{9}$ See S. West 1967.

${ }^{10}$ See Graziosi and Haubold 2011, 4n., 21n., 31n., 71n., 76n., 148n., 226n., 237n., 241n., 252n., 266n., 285n., 321-322n., 415n., 511n. [variants that elucidate the text]; 112n. [context-specific variant]; 135n., 160n. [attempts at establishing decorum]).

${ }^{11}$ Fantuzzi 2001, 174-7.

${ }_{12}$ As argued by Rengakos 1993.
} 
that it has gathered momentum in the last decade: Strauss Clay helpfully summarises:

A new interest in the performance and reception of archaic Greek poetry has...shifted the center of gravity in recent considerations of Homeric epic. Attention has moved away from the creation and evolution of the poems to questions concerning their reception by an audience and the interaction of the poet and his listeners. ${ }^{13}$

My question, however, is whether "creation and evolution" can be so neatly separated from "reception" and "the interaction of the poet and his listeners". I make the case, in this paper, that composition and reception are inextricable.

It may be helpful to start with a crude question: where composition ends and reception begins; for this question quickly reveals that no straightforward line can be drawn between the two. Reception starts, I maintain, with the Homeric text itself, and not just with the poorly attested variants I have already discussed. Our Iliad receives and responds to an earlier tradition: some epic expressions, for example, must have sounded obscure even to the earliest audiences of the poem, because internal glosses attempt to explain their meaning. The epithet $\delta$ aii $\varphi \rho \omega v$ may serve as an example, since there seems to be some uncertainty already in the Iliad as to what it might mean. Two popular etymologies are suggested in the text: one points to the meaning "warlike" (from $\delta a i$ = "battle"); the other to "wise" (cf. $\delta a \eta j \mu \omega v=$ "knowledgeable, understanding"). At 5.277, for example, we find this pair

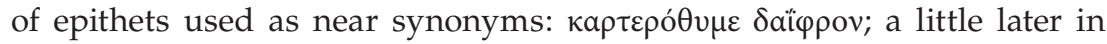
the text, at 6.162, the epithet is explained differently, in the sequence a $\gamma \alpha \theta \dot{\alpha}$

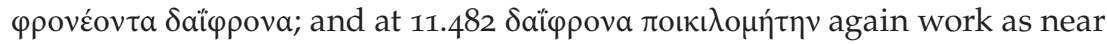
synonyms, but point to "wise" rather than "warlike". The scholia pick up the different explanations of the word $\delta a i ̈ \varphi \rho \omega v$ contained inside the text, ${ }^{14}$ and the LSJ follows suit, offering the following translations: "warlike", "fiery", "wise", "prudent". In the case of $\delta a i ̈ \varphi \rho \omega v$, then, reception is clearly linked to composition: the Iliad itself seeks to explain the epithet to live audiences in performance, the explanations are teased out by ancient scholars, and they eventually make their way into modern dictionaries.

In other cases, it is harder to pinpoint the exact relationship between the way a word is used and framed in the Iliad, and its subsequent recep-

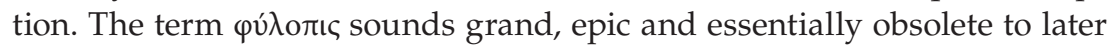
Greek authors: Theocritus, for example, uses it to describe the subject mat-

${ }_{13}$ Strauss Clay 2011, 14-15; she includes Bakker's work (e.g. 1997 and 2005) in this movement towards reception, although it seems to me to be equally concerned with composition.

${ }^{14}$ See, for example, $\mathrm{b}$ T ad $2.23 a$. 
ter glorified by the ancient bards, àotooí. ${ }^{15}$ In Hesiod's Works and Days, it characterises the age of the heroes; ${ }^{16}$ and it seems that already in the Iliad the word is beginning to sound grand and obscure, and hence to attract

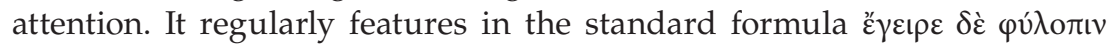

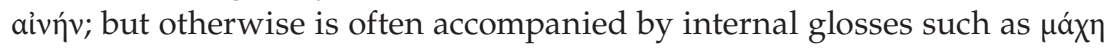
or $\pi \mathrm{o} \lambda \varepsilon \mu$ oĩo, suggesting that it can be conceived as battle, or an aspect of war. Ancient commentators suggest "din of battle"; ${ }^{17}$ but at Il. 16.256 Achil-

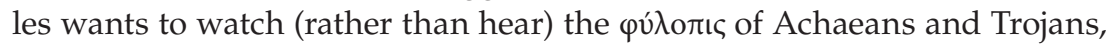
so there seems to be a degree of fuzziness about the exact meaning of this word, and some experimentation as to how it might be used. Here we may be witnessing the beginning of a speculation about a specific word in the Homeric text; and a later characterisation of that word as typical of an ancient tradition of heroic poetry.

Sometimes, the Homeric habit of explaining words, and offering etymologies for them, has direct implications for editors of the Iliad. West, as I have already suggested, is rather quick to emend the transmitted text on the assumption that Homer used correct Greek - by which he means "correct" by the standards of modern linguistic scholarship. Where the Vulgate does not conform to such scholarship, he sets out to correct the Vulgate. So, for example, West rejects the transmitted form $\pi v \varepsilon v ́ \mu \omega v$ (lung) at Iliad 4.528 on the grounds that it arose by popular etymology from older $\pi \lambda \varepsilon v ́ \mu \omega v$, which is morphologically correct and therefore what he prints. ${ }^{18} \mathrm{He}$ has slim textual support for his choice, however, because $\pi \lambda \varepsilon v ́ \mu \omega v$ is attested only in Photius and Eustathius (two Byzantine scholars) and one papyrus. So, one straightforward question is whether West is right to print $\pi \lambda \varepsilon v \mu \omega v$, or whether editors should follow the Vulgate and print $\pi v \varepsilon v ́ \mu \omega v$, as van Thiel for one does. Grammatical correctness is an obvious criterion for judging the Homeric text, but the crucial issue here (and an issue which West never addresses) concerns the text's own criteria of grammatical correctness; or, to put it differently, what early audiences may have considered acceptable in terms of morphological formation. ${ }^{19}$ Were their criteria for correctness the same as ours? And were they always the same? Assuming that $\pi v \varepsilon v ́ \mu \omega v$ is indeed a corruption, or rather an etymologising version of $\pi \lambda \varepsilon v ́ \mu \omega v$, it is

${ }_{15}$ Theocritus, Idyll 16.50 .

${ }^{16}$ Hesiod, WD 161.

${ }_{17}$ See e.g. $\Sigma b$ ad 6.1c.

${ }_{18}$ See West 1998, xxxiv: " $\pi \lambda \varepsilon v ́ \mu \omega \nu(\Delta 528=$ M 189a) verum est, non $\pi v \varepsilon v ́ \mu \omega v$, quod ex etymologia populari invasit".

${ }_{19}$ On Aristarchus' understanding of grammar, see Matthaios 1999; earlier perceptions of the Homeric text are of course even harder to reconstruct: the starting point must be the Homeric text itself, and therefore circular arguments about how it should be edited are always a risk. 
still necessary to decide whether the poet of the Iliad could use this form or, to put it differently, whether the earliest audiences of the Iliad could have made sense of it, and perhaps even appreciated it as a quick, on-the-hoof etymologising version of $\pi \lambda \varepsilon v \dot{\mu} \omega \omega v$. West rejects this possibility: popular etymology, he implies, is below the poet of the Iliad and his audiences. But, as a matter of fact, there is plenty of it in the poem. Rank's extensive study of etymologising figures in Homer (1952) only discusses part of the evidence; there would in fact be room for an even more extensive study. Chantraine magisterial Grammaire Homérique (1948-53) amply demonstrates what an important role etymological explanation plays in the formation of words; and, if any further proof were needed that Homeric word formation can be erratic (that is to say, "incorrect" by modern standards), Leumann's brilliant study Homerische Wörter (1950) ought to provide it. ${ }^{20}$ In light of such extensive and systematic work on etymologising language in Homer, it seems very hard indeed to read $\pi v \varepsilon v ́ \mu \omega v$ as a late corruption, rather than accept it as early etymological play, particularly in view of the overwhelming textual support for it.

Similar arguments to those about word formation can be applied to the issue of grammatical consistency. West tends to correct the Vulgate in order to restore a consistently ancient-looking text for Homer. So, for example, the Vulgate uses both $\mu$ o and $\mu \varepsilon v$ after $\kappa \lambda \tilde{v} \theta$. Standard Greek has the genitive $\mu \varepsilon v$; the dative $\mu$ ot represents older grammar. West argues for restoring $\mu$ o everywhere, on the grounds that it is linguistically older and was eventually, partly replaced by $\mu \varepsilon v$ under the pressure of spoken language. ${ }^{21}$ The issue is when that pressure started to bear, and whether the Homeric text was ever consistent in the use of the dative after $\kappa \lambda \tilde{v} \theta{ }^{2 .}{ }^{22}$ There are many instances where the Iliad displays linguistically older and younger forms alongside each other. The ancient letter digamma is the most famous example, of course: if there is anything consistent in Homer's use of it, then it

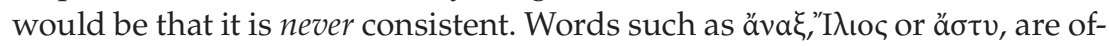
ten used as though they were still pronounced wanax, Wilios, wastu, as they certainly were early in the tradition. But on some occasions, they function like any other word starting with a vowel. It may be objected that digamma

\footnotetext{
${ }^{20}$ On Leumann's superb monograph, see Dihle 1970. On Homeric word formation, see also Meister 1921 and Hackstein 2002.

${ }^{21}$ See West 1998, xxxii: "At praestat $\mu$ ol, quod antiquius videtur syntagma quodque genitivo vulgari cessurum erat. Non est credibile, poetam modo hoc modo illud dixisse." Van Thiel 1991, xxiv-xxv, disagrees, retaining inconsistency, with this argument: "We cannot assume that the creators and users of the Homeric language consistently dispensed with possible alternatives with an eye to a kind of economy whose laws we determine intrepidly."

${ }^{22}$ See further Meier-Brügger 1986.
} 
is dropped only in exceptional cases, and for metrical reasons, but metrical constraint can never fully account for the phenomenon, because it is still necessary to explain why metre was allowed to have such influence on language. ${ }^{23}$ At the very least, the use of digamma suggests that metre was felt to be more important than morphological consistency.

Moreover, the example of $\tilde{\varepsilon} \omega \varsigma$ shows that even metrical need could not quite counteract the pressure of spoken language surrounding Homeric performances. At some point in the epic tradition the formulaic line $\tilde{\varepsilon} \omega \varsigma \mathrm{o}$

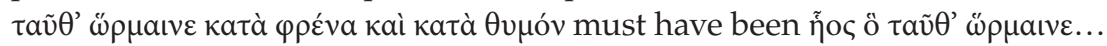
Then Ionic metathesis set in and changed the singers' pronunciation to $\tilde{\varepsilon} \omega \varsigma$ - and this created a serious breach of metrical regularity, because the resulting verse now starts with a short syllable. Accordingly, some editors change $\varepsilon \omega \varsigma$ back into ๆ̃oৎ in order to preserve metrical consistency (even though there is no textual support for this change at all); but here West rightly argues that the issue is not that of faulty transmission, but rather that of mistaken assumptions, on our part, about what is possible in Homeric metre: as he points out, the rhapsodes did not wonder whether their verses were "metrical" in the sense of fitting into some abstract metrical scheme. ${ }^{24}$ They rather struck a balance between the tradition they inherited and the pressures exerted by the language spoken around them. Modern standards of consistency should not obscure the question of what sounded possible to ancient audiences. In the case of $\mu \mathrm{ol}$ and $\mu \varepsilon v$, the Vulgate reports a mixture of forms, and there is no reason to suppose that such a mixture would have sounded unacceptable to early audiences of the Iliad. As Janko points out in his review of West's edition, "one can disagree, not about the sequence of phonetic changes, but where Homer falls in relation to them". ${ }^{25} \mathrm{It}$ is quite possible to imagine that poet and audiences converged on an unstable compromise between the epic tradition they inherited and the language they spoke. All the evidence points precisely to that kind of compromise; so modern attempts to arrive at the purest, most consistent, and earliest sounding text seem misguided in principle.

Indeed, the modern quest for morphological consistency can at times even obscure ancient evidence for the interpretation of Homeric epic. For example: there are two expressions in Homer which look similar but, according to the medieval Vulgate, were spelled and pronounced differently:

\footnotetext{
${ }^{23}$ Here the work of Parry (e.g. 1932 and 1971) is especially influential, and has naturalised arguments about metrical convenience.

${ }^{24}$ West 1967, 139: “Die Rhapsoden haben sicher nicht überlegt, ob ihre Verse ,metrisch' waren, d.h. ob sie in irgendein abstraktes Schema hineinpaßten."

${ }^{25}$ Janko 2000, 1.
} 


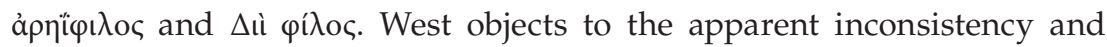

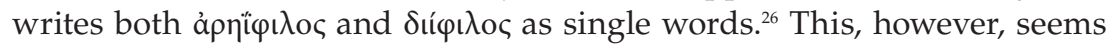
problematic in view of the meaning of these adjectives in the Iliad. The epi-

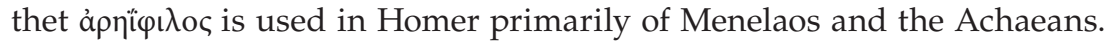
Neither is particularly dear to Ares who of course fights on the Trojan side. The expression, then, has little narrative resonance in Homer, and in fact serves as a metrically useful alternative for the common epithet ápíioc, "warlike" (again most commonly used of Menelaos and the Achaeans). The

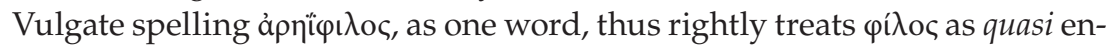
clitic. The situation is very different with $\Delta \grave{\text { ì }} \varphi$ íloc. This expression is used of people who are actually dear to Zeus, primarily Hector. It hardly ever occurs in the plural, because Zeus' preferences tend to focus on individuals. There is only one exception, at Iliad 8.517, and it confirms the rule: heralds

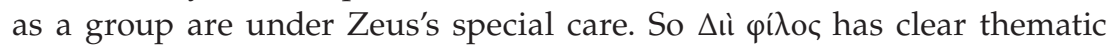

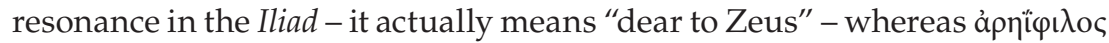
does not mean "dear to Ares", it just means warlike. Of course, there was no word division in the early texts of Homer but, as West recognizes, the argument is not about how we divide up words on a page, but rather how they were pronounced in performance: $\varphi$ í $\lambda_{o \varsigma}$ loses its emphasis in ả $\rho \eta \ddot{\imath} \varphi \iota \lambda$ oc but

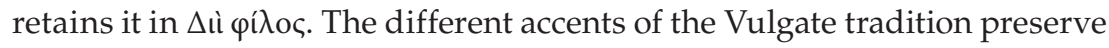
knowledge about how these words were uttered in performance. ${ }^{27}$ As every actor knows, pronunciation is the beginning of interpretation; and here the Vulgate preserves an oral interpretation of the text, which West sacrifices in the name of morphological consistency.

The evidence seems to be mounting in favour of the Vulgate (and hence van Thiel's cautious approach), and against radical attempts to correct it in order to restore a consistent, and ancient-sounding text. As for the Homeric multitext, blanket acceptance of all variants seems problematic, since some are marginal in every sense of the word. Others, however, may well represent significant early alternatives, and it is interesting that they tend to cluster in specific ways. For example, lines that introduce or round off speeches display a greater degree of variability than the speeches themselves. This is something that Stephanie West observes in her 1967 book on the Ptolemaic papyri, but which she does not further explore or

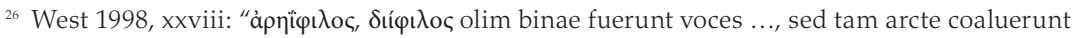

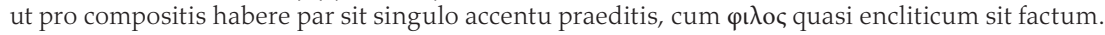

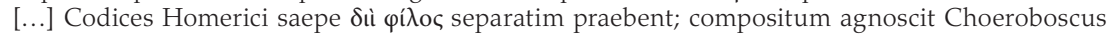
Orthogr. 192.16."

${ }_{27}$ On the relationship between the earliest texts of Homer and oral performance, see the judicious and helpful assessment by Cassio 2002. 
explain. ${ }^{28}$ What I would like to suggest here is that these variants are again evidence for the early interpretation of Homeric epic in performance. The lines that frame a speech offer the first commentary on it: they tell audiences something about the speech they are about to hear, and afterwards give some indication of the effect it had. For example, at the beginning of Iliad 6, Adrestos grabs Menelaos' knees and begs him to spare his life. Menelaos (who is a little soft in the Iliad) is "persuaded" or "moved" to save him, but Agamemnon intervenes, with an exceptionally brutal speech, and thus either "turns" or "persuades" Menelaos that Adrestos should be killed, like all other Trojans. The passage is worth quoting in full (Iliad 6.37-65):

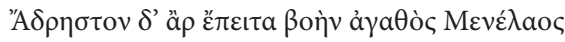

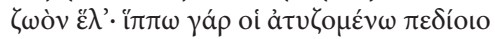

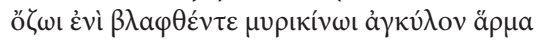

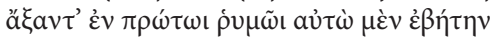

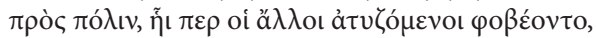

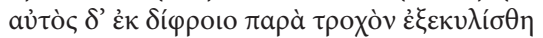

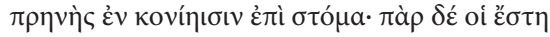

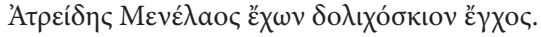

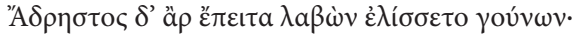

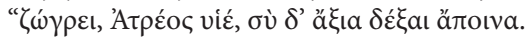

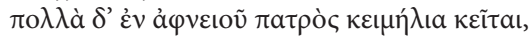

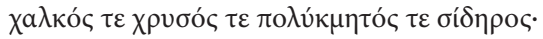

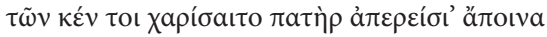

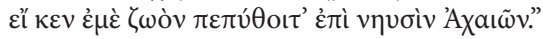

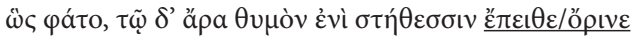

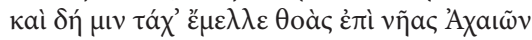

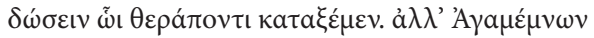

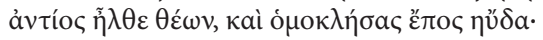

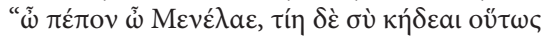

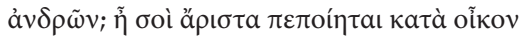

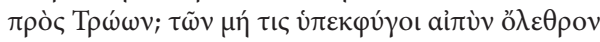

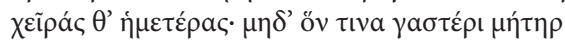

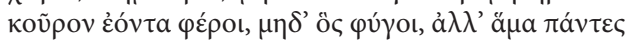

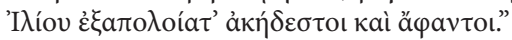

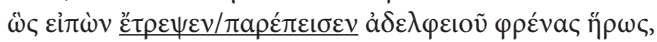

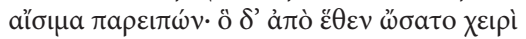

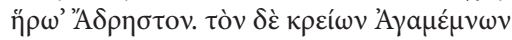

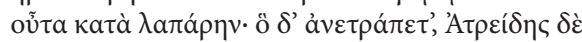

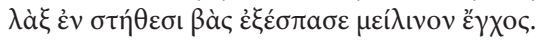

${ }^{28}$ See West 1967, 114 et passim: "The interchange of formulae introducing a speech is common." 
Next Menelaus, master of the war-cry, captured Adrestus alive. His horses, bolting in panic over the plain, had tripped over a tamarisk branch and broken the pole away where it was joined to the curved chariot, and had run off on by themselves towards the city, where the rest of the Trojans were fleeing in terror. Adrestus was whirled out of the chariot next to the wheel, head first on to his face in the dust. Menelaus Atreus' son stood over him, holding his far-shadowing spear, and Adrestus grasped him by the knees, entreating him: "Son of Atreus, take me alive, and accept a fitting ransom; there is much treasure stored up in my rich father's house, bronze and gold and elaborately worked iron, from which my father would gladly give you a boundless ransom, if he learnt that I was alive by the ships of the Achaeans."

So he spoke, and would have persuaded/moved the heart in Menelaus' breast; he was about to hand him over to his attendant to escort to the swift ships of the Achaeans, but Agamemnon ran up and stood before him, and berated him loudly: "My dear brother Menelaus, why so concerned for other men?

Can it be that you were so generously treated by Trojans back in your own home? Let not one of them escape sheer ruin at our hands, not even the man-child which a mother carries in her womb, not even him, but let them all be obliterated from Troy, to vanish unremembered."

So speaking the hero turned his brother's purpose/persuaded him; urging what is right; and Menelaus thrust the hero Adrestus from him with his hand, and lord Agamemnon stabbed him in the side. Adrestus fell back, and Atreus' son set his heel on his chest and pulled out the ash spear. ${ }^{29}$

Interpretation is difficult, partly because the poet claims that Agamemnon speaks what is right, but ancient and modern readers tend to find his speech exceptionally savage. ${ }^{30}$ When Agamemnon insists that even male foetuses still in their mothers' wombs should be killed, it is hard not to think of Astyanax, especially as this passage immediately precedes the scene where Hector and Andromache smile at their baby boy. Issues of interpretation are linked to the textual variants. At line 51, one unedited Oxyrhynchus papyrus (1044 West) reads $\varepsilon \varepsilon_{\varepsilon} \imath \varepsilon \varepsilon$, as do some of the more important manuscripts. Most manuscripts, however, have ö the Iliad, $\theta v \mu$ òv ópiv $\omega$ is used when a highly emotional act of supplication

${ }_{29}$ Translation by Verity 2011, adapted.

${ }_{30}$ On the poet's comment, see Goldhill 1990, 376, and Graziosi and Haubold 2011, ad 62. On ancient and modern reactions to Agamemnon's speech, see $\Sigma$ bT ad 6.62a; Fenik 1986, 26; Kirk 1990, 191; Yamagata 1994, 118; Wilson 2002, 166-7; and Stoevesandt 2004, 152-5. 
is successful (cf. 9.595 and 24.465-7), so the uncertainty here concerns the emotional impact of Adrestos' speech on Menelaos. Now, it may be that one reading is preferable to the other - $\varepsilon^{\prime \prime} \pi \varepsilon \theta \varepsilon \varepsilon$ is perhaps the better option, because Adrestos does not make an especially strong appeal for pity; but what the variants show is a difference of interpretation. Ten lines later, there is again variation in the speech concluding line: Agamemnon "changes" Menelaos' mind or - according to some manuscripts - "persuades him". Now here too there is, I think, a way of preferring one reading to the other: $\pi \alpha \rho \varepsilon ́ \pi \varepsilon \varepsilon \sigma \varepsilon v$, is otherwise used in the Iliad when the speaker has a restraining effect on the addressee (cf. e.g. 7.120, 13.788 and 23.606), and this is certainly not the case here. But the variants at the end of both speeches show that their tone, and Menelaos' precise reaction to them, was debated. It seems that what we have here are early, rhapsodic variants, framing the speeches in performance. It may be relevant that Plato's Ion takes special pride in the lively way he delivers Homeric speeches: it may be that, depending on the exact inflection and tone the rhapsode lends to a speech, specific lines are then chosen to conclude it. ${ }^{31}$ Our variants are thus best taken as flexible and somewhat fluid interpretative "frames" around the speeches of Adrestos and Agamemnon. Variations in speech-introductory and speech-concluding lines may, more generally, be treated as evidence for the reception of Homeric speeches on the part of rhapsodes and their audiences.

Taken together, the examples presented in this paper aim to show that reception and composition are inextricably bound. Explanations of obscure epic words like $\delta a i i \varphi \rho \omega v$ are already contained in the Iliad itself: they affect its composition, therefore, and not just the ways in which the poem is explained by later scholars. Similar arguments can be made about other aspects of the transmitted text. The evidence may not support a model of multitextuality on a grand scale, but does suggest live interpretation in performance, starting from pronunciation, and extending to the framing of controversial speeches, such as the ones I have just considered from book 6 . Editors who fail to engage with ancient reception - by asking, for example, what might or might not have sounded grammatical, inconsistent or problematic to ancient audiences - miss important evidence for the constitution of the text. Conversely, however, reception studies cannot simply take the text as given. Some of the best evidence for the ancient reception of epic is, in point of fact, contained in the apparatus criticus. ${ }^{32}$

${ }^{31}$ See Plato, Ion $535 \mathrm{c}-\mathrm{e}$

${ }^{32}$ I would like to thank Johannes Haubold, Christian Werner, and audiences at São Paulo and Glasgow for their responses to earlier versions of this paper.

Email da autora: barbara.graziosi@durham.ac.uk 


\section{BIBLIOGRAPHY}

Bakker, E. J. 1997. Poetry in Speech: Orality and Homeric Discourse. Ithaca, NY-London: Cornell University Press.

Bakker, E. J. 2005. Pointing at the Past: From Formula to Performance in Homeric Poetics. Cambridge, MA: Center for Hellenic Studies.

Battezzato, L., ed. 2003. Tradizione testuale e ricezione letteraria antica della tragedia greca. Amsterdam: Adolf M. Hakkert.

Cassio, A. C. 2002. "Early editions of the Greek epics and Homeric textual criticism". In Omero tremila anni dopo, ed. F. Montanari, 105-136. Rome: Edizioni di Storia e Letteratura.

Chantraine, P. 1948-1953. Grammaire Homérique. Paris: Klincksieck. 2 v.

Erbse, H. 1968-1988. Scholia Graeca in Homeri Iliadem. Berlin: de Gruyter. 7 v.

Dihle, A. 1970. "Leumanns Homerische Wörter und die Sprache der mündlichen Dichtung". Glotta 48: 1-8.

Fantuzzi, M. 2001. "'Homeric' formularity in the Argonautica of Apollonius of Rhodes". In A companion to Apollonius Rhodius, ed. T. D. Papanghelis \& A. Rengakos, 171-92. Leiden: Brill.

Fenik, B. 1986. Homer and the Nibelungenlied. Cambridge, MA: Harvard University Press.

Finkelberg, M. 2000. "The Cypria, the Iliad, and the problem of multiformity in oral and written tradition." Classical Philology 95: 1-11.

George, A. 2003. The Babylonian Gilgamesh Epic: Introduction, Critical Edition and $\mathrm{Cu}$ neiform Texts. Oxford: Oxford University Press.

Goldhill, S. 1990. "Supplication and authorial comment in the Iliad: Iliad Z 61-2". Hermes 118: 373-6.

Graziosi, B.; Haubold, J. 2010. Homer: Iliad VI. Cambridge: Cambridge University Press.

Hackstein, O. 2002. Die Sprachform der homerischen Epen. Faktoren morphologischer Variabilität in literarischen Frühformen: Tradition, Sprachwandel, sprachliche Anachronismen. Wiesbaden: Dr. Ludwig Reichert.

Janko, R. 2000. “West's Iliad". Classical Review 50: 1-4.

Kirk, G. S. 1990. The Iliad: A Commentary. Cambridge: Cambridge University Press.

Labarbe, J. 1949. L'Homère de Platon. Liège: Bibliothèque de la Faculté de Philosophie et Lettres de $\mathrm{l}^{\prime}$ Université de Liège.

Leumann, M. 1950. Homerische Wörter. Basel: Friedrich Reinhard.

Matthaios, S. 1999. Untersuchungen zur Grammatik Aristarchs: Texte und Interpretation zur Wortartenlehre. Göttingen: Vandenhoeck \& Ruprecht.

Meier-Brügger, M. 1986. "Homerisch $\mu \varepsilon v$ oder $\mu$ ot?" In O-o-pe-ro-si. Festschrift für Ernst Risch zum 75. Geburtstag, ed. A. Etter, 346-54. Berlin and New York: de Gruyter.

Meister, K. 1921. Die homerische Kunstsprache, Leipzig: Teubner.

Nagy, G. 2000. "Review of West 1998". Bryn Mawr Classical Review, 2000.09.12.

Nagy, G. 2003. "Review of West 2001". Gnomon 75: 481-501.

Nardelli, J.-F. 2001. “Review of West 2001". Bryn Mawr Classical Review, 2001.06.21. 
Parry, M. 1932. "Studies in the epic technique of oral verse-making: II. The Homeric language as the language of an oral poetry". Harvard Studies in Classical Philology 43: 1-50.

Parry, M. 1971. The Making of Homeric Verse. The Collected Papers of Milman Parry. Oxford: Oxford University Press.

Rank, L. Ph. 1952. Etymologiseering en verwante verschijnselen bij Homerus. Assen: Van Gorcum.

Rengakos, A. 1993. Der Homertext und die hellenistischen Dichter. Stuttgart: Franz Steiner.

Rengakos, A. 2002. "Review of West 2001". Bryn Mawr Classical Review, 2002.11.15.

Stoevesandt, M. 2004. Feinde - Gegner - Opfer. Zur Darstellung der Trojaner in den Kampfszenen der Ilias. Basel: Schwabe.

Strauss Clay, J. 2011. Homer's Trojan Theater. Cambridge: Cambridge University Press.

Thiel, H. van. 1991. Homeri Odyssea. Hildesheim: Olms Weidmann.

Thiel, H. van. 1996. Homeri Ilias, Hildesheim: Olms Weidmann.

Verity, A. 2011. Homer: The Iliad. Introd. and not. B. Graziosi; trans. A. Verity. Oxford: Oxford University Press.

West, M. L. 1967. "Epica”. Glotta 44: 135-48.

West, M. L. 1973. Textual Criticism and Editorial Technique Applicable to Greek and Latin Texts. Stuttgart: Teubner.

West, M. L. 1998-2000. Homeri Ilias. Stuttgart-Leipzig: Saur. 2 v.

West, M. L. 2001. Studies in the Text and Transmission of the Iliad. Munich-Leipzig: Saur.

West, M. L. 2001. "West on Nagy and Nardelli on West". Bryn Mawr Classical Review 2001.09.06.

West, M. L. 2004. “West on Rengakos (BMCR 2002.11.15) and Nagy (Gnomon 75, 2003, 481-501) on West". Bryn Mawr Classical Review 2004.04.17.

West, S. 1967. The Ptolemaic papyri of Homer. Cologne: Westdeutscher Verlag.

Wilson, D. 2002. Ransom, Revenge, and Heroic Identity in the Iliad. Cambridge: Cambridge University Press.

Yamagata, N. 1994. Homeric Morality. Leiden: Brill.

\section{*}

Abstract. This paper aims to contribute to two areas of Homeric scholarship which seldom seem to engage in productive dialogue: textual criticism and reception studies. It assesses three different approaches to the text of Homer: H. van Thiel's editions of the Iliad and the Odyssey, Martin West's Iliad for Teubner, and Gregory Nagy's multitext approach; simultaneously, it takes seriously the growing emphasis on reception in classical scholarship. By considering textual variants, morphology and syntax, this paper illustrates how the study of reception may contribute to the constitution of the text and, vice versa, how the history of the Homeric text illuminates its broader reception. Keywords. Homer, textual criticism, reception, textual variants, morphology, syntax. 